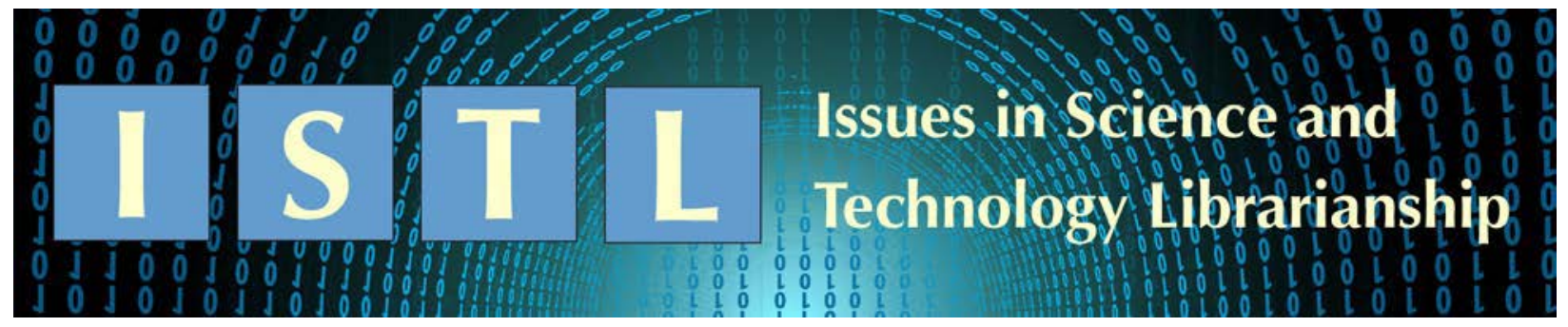

\title{
Implementing Information Literacy (IL) into STEM Writing Courses: Effect of IL Instruction on Students' Writing Projects at an Urban Community College
}

\author{
Miseon Kim \\ Science Librarian/Assistant Professor \\ Queensborough Community College \\ Bayside, New York \\ mkim@qcc.cuny.edu \\ Mercedes Franco \\ Chair of Mathematics and Computer Sciences/Associate Professor \\ Queensborough Community College \\ Bayside, New York \\ mfranco@qcc.cuny.edu \\ Dugwon Seo \\ Assistant Professor of Engineering Technology \\ Queensborough Community College \\ Bayside, New York \\ dseo@qcc.cuny.edu
}

\begin{abstract}
The purpose of this study was to implement information literacy (IL) into Science, Technology, Engineering, and Mathematics (STEM) writing courses at an urban community college, investigate if students' information literacy (IL) skills were improved through library one-shot instruction, and determine if there was an association between IL skills and students' writing performance. Students in the experimental group attended the library instructional class and students in the control group had no library class. Students' research papers were scored using the Association of American Colleges \& Universities (AAC\&U) Information Literacy VALUE Rubric to grade the effectiveness of the library instruction (Association of American Colleges and Universities 2013). While the scores of the papers did not differ between groups, data indicated that there was a statistically significant difference ( $p=$ $.011)$ in IL scores between students in the experimental group $(M=9.70)$ and students in the control group $(\mathrm{M}=8.73)$. The results also showed that information literacy skills were correlated positively with students' grades on research papers $(p=.002)$.
\end{abstract}




\section{Introduction}

Information literacy (IL) skills are required across all disciplines in higher education, including Science, Technology, Engineering, and Mathematics (STEM). The ALA/ACRL/STS Task Force on Information Literacy for Science and Technology developed IL standards for science and engineering/technology in higher education settings. Information literate students should have the ability to identify, evaluate, and use information in an ethical and legal matter in various formats to keep abreast with new technology and developments (American Library Association 2006). IL skills are an essential life-long preparation for STEM students in higher education that allows them to keep up with changing technology (Balint 2016). Literature has stressed the need for information literacy to be implemented in the first year of college STEM education because early exposure is beneficial for students (Barsky et al. 2011; Wilkes et al. 2015; Salisbury \& Mattice 2016). However, according to a survey conducted by Library Journal in conjunction with Credo, discipline-specific information literacy instruction was offered less to science disciplines than other disciplines in the first-year at 4-year or 2-year colleges and universities (Library Journal 2017). It can be challenging to implement IL into STEM disciplines in the first year because courses at this level often focus on delivering content knowledge of the textbooks and require no writing. As a result, information literacy components may not be included within the first year STEM curriculum (Bussmann \& Bond 2018).

At Queensborough Community College (QCC) of The City University of New York (CUNY), it is voluntary for faculty to include IL session(s) for their classes because IL courses are not credit-bearing. Upon request from faculty, librarians deliver either "one-shot" or embedded multiple IL sessions to a course. Although information literacy instruction has been popular in general, it has not been widely adopted by STEM faculty at QCC. In the fall of 2017, out of a total 207 IL sessions, most of them were requested by faculty from the English department $(57 \%, n=118)$ and Speech Communication \& Theatre Arts department $(19 \%, n=39)$, while only about $3 \%(n=6)$ of IL instruction was offered for STEM disciplines (Wengler 2017).

At QCC, students are required to take two writing intensive (WI) courses before graduation. Students enrolled in any WI courses are required to write a paper, which creates a great opportunity for the science librarian to reach out to STEM faculty who might be interested in including information literacy in their WI courses. When the science librarian was hired in 2014, there were no IL sessions for any science courses, but an effort to reach out to STEM faculty convinced them to bring their classes to an information literacy session over the years. In the fall of 2019, 12 information literacy sessions were scheduled for the STEM courses compared to 6 IL sessions were offered in the spring of 2019. The number of requests of IL instruction from STEM faculty has been growing very slowly, but steadily at QCC.

This paper describes how IL was incorporated into STEM writing courses, reports the results of student IL skills after a one-shot IL session, and discusses the relationship between IL skills and students' writing performance.

\section{Literature Review}

Over the last ten years, academic librarians have been in collaboration with faculty to engage in assessing IL competency based on the ACRL Framework and its impact on student learning. It has been emphasized that implementing IL across all disciplines (including STEM) and assessing student learning are important in promoting the value of academic libraries in the institution. The literature shows that academic librarians have sought to prove to stakeholders that libraries could contribute to the 
institution’s pedagogical goals (Oakleaf 2010; Jantti \& Cox 2013; Oakleaf et al. 2017). Research has also demonstrated the importance of implementing IL in STEM disciplines, reporting how IL supports STEM courses or curricular outcomes (Scaramozzino 2010; Ferrer-Vinent 2016; Salisbury \& Mattice 2016; Rose-Wiles et al. 2017; Phillips \& Zwicky 2018; Sloane et al. 2018). Academic librarians have been involved in assessing student learning with regard to the impact of IL on STEM course writing and/or GPA and that is what has been investigated in this study (IL and writing). Some studies developed IL outcomes in line with curriculum or institutional outcomes and assessed the results (Scaramozzino 2010; Sloane et al. 2018). Others have explored the relationships between IL skills and student retention or graduation (Haddow 2013; Crawford 2015; Catalano \& Phillips 2016), however this is outside the focus of this paper.

The purpose of this study was to assess students' IL skills as well as impact of IL on STEM writing performance in a community college where most students might be academically underprepared for college level work. However, when the authors conducted a literature search on information literacy in STEM disciplines (IL in STEM) in 2017, we found that studies on IL in STEM at the two-year institutions were noticeably less published in the scholarly peer-reviewed literature compared to studies at the four-year universities. In October, 2019, we conducted research using CUNY OneSearch and EBSCOhost. The following combination of keywords was used: ("information literacy" OR "one-shot" OR "library instruction" OR "library session") AND (science OR stem OR biology OR engineering OR physics OR math? OR technology). For community colleges, the keywords added to the search were ("community college?" OR "two-year college?" OR "junior college?"). A truncation question mark (?) was a wildcard for OneSearch and an asterisk (*) was used in EBSCOhost.

The search inquiry in CUNY OneSearch, which collects sources from the CUNY library catalog, periodicals, and digital content, yielded 46,684 peer-reviewed articles on IL in STEM within a range of 20 years $(1999-2019)$. About 3 percent $(n=1573)$ of the search results on IL in STEM were studies performed at the community college level and published in peer-reviewed journals. The same literature search was conducted in October, 2019, using EBSCOhost databases combining Education Source, ERIC, Library \& Information Science Source, MAS Ultra School Edition, Professional Development Collection, and Teacher Reference Center. It was limited to peer-reviewed journals from 1999 to 2020 and AB field (for Abstract) was used to search only in abstract summaries. Among a total of 2,674 results, less than 2 percent $(n=44)$ belonged to studies on IL in STEM fields at community colleges or two-year institutions. Based on the results from these two searches in the library databases, publication of peer reviewed studies involving IL in STEM at community colleges is far less frequent compared to the studies at 4-year universities.

While conducting research on IL in STEM, we found that there had been studies focused on faulty perception of IL. This led us to consider whether this could have been a factor that kept faculty from implementing IL in their courses, especially in STEM disciplines at the community college level. The authors felt that it was worth mentioning how IL was viewed by STEM faculty. Therefore, the literature review includes (1) studies of STEM faculty perception of IL, (2) studies on how academic librarians have implemented IL in STEM disciplines in 4-year and 2-year institutions, and (3) studies on IL skills in STEM courses or curriculum with regard to student learning, especially writing or GPA.

\section{STEM Faculty Perception of IL}

Leckie and Fullerton (1999) surveyed and interviewed faculty about their perception of information literacy at the University of Waterloo and the University of Western Ontario, both of which have a large body of science and engineering faculty. The survey results revealed that faculty from science and engineering did not utilize IL because they believed it was not necessary in their courses. The qualitative 
surveys from Sociology and Civil Engineering faculty in the Republic of Ireland (McGuinness 2006) revealed that faculty believed developing IL skills would depend on individual efforts and students' willingness to learn on their spare time. One of the major barriers to inclusion of IL in courses was that faculty assumed students would learn IL from peers and colleagues somehow during their academic life. In other words, IL was not something that should be taught through course or curriculum pedagogies because students would pick up those skills along the way somehow. The findings of Saunders' study (2012) indicated that information literacy was highly regarded by faculty from all disciplines. But because faculty might not be aware that librarians could contribute to student learning, they might not include IL in the course. Saunders claimed that if faculty were aware of IL standards, they would incorporate more IL into their courses. The results of a survey conducted at 2-year and 4-year institutions located in New Jersey during 2011 and 2012 (Dubicki 2013) showed that faculty expected students would achieve IL skills by the time of graduation, but realized they did not master those skills by the end of their programs. Overall, faculty expectations for students' IL skills were higher than the students' actual IL skills. Cope and Sanabria (2014) interviewed faculty at a four-year university and a community college in CUNY. They found that regardless of whether faculty work at a four-year college or a community college, they had a tendency not to include IL instruction because they believed information literacy had already been integrated into their courses. Their study confirmed what Gullikson (2006) found, which was that faculty expected students to already have IL skills in the first year of college or in high school. Similarly, researchers in other studies determined that faculty expected students to already have IL skills, but found out later that students needed to develop these skills for the course (Sandercock 2016; Perry 2017). A survey study at a CUNY community college revealed that IL was less appreciated by STEM faculty because they felt IL instruction was not relevant to the course or they perceived that they would not be able to find time to include IL instruction because of contentdriven syllabi (Ward \& Kim 2019). In a recent qualitative study conducted at Anglia Ruskin University in the UK, the interviews of faculty and academic staff revealed that faculty viewed IL as an "extension" to the subject content, not as a separate discipline (Stebbing et al. 2019). However, the academic staff considered IL as transferable skills across all disciplines. This resonates with what is noted in Saunders' study (2012), which is that some faculty members believe IL belongs in general education and should be incorporated into core composition or first year curriculum.

Poe and Lewitt (2006) conducted a survey of first year MIT students in communication intensive courses (the term "communication intensive” was used at MIT in lieu of writing intensive). The researchers discovered that students perceived writing as an inborn skill and not relevant to a career in science, engineering, or mathematics. Students majoring in STEM subjects did not recognize the value of writing. Poe and Lewitt asserted that in reality students should be able to write technical reports or grant proposals at the workplace. To achieve this, they should be equipped with research skills. Scharf (2014) also supported Poe and Lewitt's claim that engineering students would need IL skills if they hoped to be successful professionals.

\section{Implementing Information Literacy in STEM}

The importance of implementing IL into first-year STEM courses has been emphasized in the literature. Barsky et al. (2011) stressed the importance of teaching information literacy to undergraduate engineering students in the first two years to effectively impact student learning in academia. Salisbury and Mattice (2016) argued that it is beneficial to expose undergraduate chemistry students to information literacy at an early stage of education. However, according to the first-year experience survey administered by Library Journal, in conjunction with Credo Reference, that was performed at 4year and 2-year academic institutions in 2017, within schools that provided discipline-specific information literacy courses, 69\% offered customized information literacy (IL) instruction for language 
\& literature majors, $46 \%$ for social sciences, $43 \%$ for communications, and $15 \%$ provided IL instruction for sciences (First-year experience survey 2017). Although the survey did not present the results of the discipline-specific IL courses offered by type of institution, it showed that customized IL was less implemented in science disciplines than other disciplines in the first year regardless of whether they were 4-year or 2-year colleges and universities.

However, the literature shows that academic librarians in 4-year institutions, in collaboration with faculty, have attempted to implement IL into STEM courses or curricula at all levels. In an effort to integrate IL into the curriculum of the College of Science and Mathematics (COSAM) at Cal Poly State University, faculty and librarians created the COSAM curriculum which was aligned with University Learning Objectives, shared departmental learning outcomes, and ACRL IL Standards for Science and

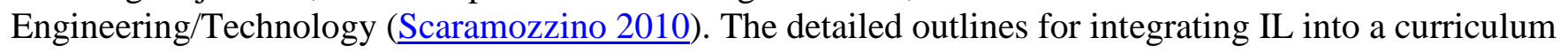
would be helpful to librarians if they wish to adopt the process. Ferrer-Vinent (2016), a science librarian at the University of Colorado, after years of reaching out to STEM faculty, developed programmatic, scaffolded IL instruction and embedded it into an organic chemistry lab. All of the students enrolled in organic chemistry received information literacy instruction. Ferrer-Vinent emphasized that librarians should be patient because it may take years of effort to implement IL into a STEM course. After piloted integration of IL into a writing-designated applied math course for senior math majors, researchers concluded that students really needed IL skills and that IL instruction should be integrated into the curricula "vertically from lower-class divisions to upper-class divisions and horizontally across courses at each level” (Gross et al. 2016). At Shippensburg University, a public four-year university, a STEM librarian piloted library instruction to one section of a MAT 110 course (Fundamentals of Mathematics) and found that students were able to identify reliable sources, but needed more practice in citation (Albro et al. 2018). Librarians at Middle Tennessee State University collaborated with STEM faculty and piloted lesson plans for General Biology 1110 and a Mineralogy course for Geology majors (Sloane et al. 2018). The learning goals were created based on the new ACRL Framework and after the implementation the authors (Sloane et al. 2018) found that IL learning outcomes were not aligned well with curricular learning outcomes, which resulted in difficulty assessing student learning outcomes.

Biology instructors and a librarian at Hostos Community College selected General Education competencies and integrated them into a sequence of Biology I (BIO210) and Biology II (BIO220) courses for three academic years (Henderson 2011). Students in BIO210 took multiple library workshops and students in BIO220 took one session of library instruction. The authors assessed whether skills were transferred to BIO220. The confidence in using library resources increased from $17 \%$ in $\mathrm{BIO} 210$ to $88 \%$ in $\mathrm{BIO} 220$. Students in BIO 220 utilized more peer-reviewed resources than they did in BIO210. The study also indicated that over the course of two semesters the students had not developed some skills, such as selecting a research topic. Henderson's (2011) study was unique not only because it was conducted at a community college, but also because it was designed to measure students' IL skills for three academic years.

\section{Information Literacy Skills \& Student Learning in STEM Fields}

In terms of information literacy skills, studies have shown that after IL instruction students improved some IL skills while other IL skills were still in need of improvement. Sophomore students who took an organic chemistry class (Chemistry 254) in Miami University received 14\% higher bibliography scores after they attended library instruction than students who did not attend the library session. Students who received library instruction utilized more scholarly sources, but they still struggled with citing in ACS style regardless of their attendance of library sessions (Kromer 2015). Studies indicated certain IL skills improved after the library instruction. Students' grades for the quality and use of references in the lab reports increased by about 25\% after librarians were embedded into an introductory Biology 1201 Lab 
(Rose-Wiles et al. 2017) and student self-efficacy with patent searching increased in the Mechanical Engineering Design course in Purdue University (Phillips \& Zwicky 2018). Librarian-led scaffolded IL instruction helped students in STEM writing courses identify science primary research articles using library databases and format references on the topic (Klucevsek \& Brungard 2016). In this case, students were given feedback from the science librarian. Klucevsek and Brungard (2016) claimed that after the librarian-led IL instruction, students have increased abilities to distinguish between primary research articles and secondary research articles. However, other studies, similar to the findings of Kromer (2015), revealed that students still grappled with the ethical use of information even after the library intervention. The findings of Zhang et al. (2015) pointed out the first-year engineering students' lack of understanding of how to cite sources. The pilot study of Albro et al. (2018) also found that students who enrolled in MAT 110 (Fundamentals of Mathematics) struggled with citing sources properly after the library instruction.

The studies of the relationship between information literacy and student performance in GPA or writing have been mixed. Scharf (2014) reported that students in the experimental groups received higher scores in the posttest than those in the control group, who enrolled in the upper division engineering undergraduates in the New Jersey Institute of Technology. It was also found that GPA correlated significantly with pretest and posttest information literacy score. Wilkes et al. (2015) demonstrated the value of collaboration between librarians, faculty and advisors and the importance of information literacy and writing skills for first year engineering students' success. Waters (2015) also showed how a joint effort between librarians and instructors could improve students’ IL skills as well as writing competency. A U.K. study by George and Munshi (2016) examined if there were relationships between degree grade (equivalent to GPA in the US education system) and library services. Although there was no relationship between degree grade and library visits, a relationship was found between degree grade and usage of library books and electronic databases. According to the findings of Flierl et al. (2018), among IL skills, only the ability of synthesizing and communicating information had a relationship with course performance. Students were motivated, engaged, and performed better when instruction was geared to foster high-order IL skills such as synthesizing information and communicating the results, but students were less engaged when activities were less motivating such as skills of evaluating information and applying conventions of attribution. The survey of Flierl et al. (2018), developed based on AAC\&U IL VALUE, was conducted on students from all disciplines such as Agriculture, Education, Engineering, Health and Human Sciences, Liberal Arts, School of Management, Science, and Technology, including 102 course sections from 44 different courses taught at a large public university in the Midwest. Although the study was not directly about IL in STEM disciplines at the community college, the findings of the study (Flierl et al. 2018) could help the authors of this paper understand why students would not be able to develop a certain area of IL skills such as synthesizing and communicating information with one-shot library instruction.

\section{Methods}

Given that information literacy is considered an important component for student learning in STEM fields, the research presented here was carried out to verify the effectiveness of the IL instruction: improvement of the students' IL skills through one-shot library instruction and the relationship between IL skills and STEM writing performance. The Methods section describes how a pilot study started, the lessons that were learned from the pilot study, which STEM courses participated, how the research was designed, and the methods of the data collection. Both the pilot project and the revised project were approved by the Institutional Review Board. 


\section{Pilot Study}

The science librarian met a faculty member at one of the High Impact Practices workshops at QCC in 2016 and decided to pilot a study with two sections of a MA 336 Statistics writing intensive course. In the experimental group, IL sessions were embedded into the course, while in the control group there was no IL session. Both groups were taught by the same instructor. Students in the experimental group participated in a two hour in-class IL instruction. Having two separate IL sessions was not feasible due to a busy course syllabus. Therefore, students were required to attend another two hour IL session outside of class and encouraged to set up consultations with the embedded librarian. However, students found it difficult to attend additional IL instruction outside of the class and did not make time for consultation. A couple of lessons were learned from the pilot study. Allotting multiple IL sessions to the course was not practical and the library sessions had to be held during students' regular class time.

The results of the pilot study were similar to the results of the revised project: it showed that students' IL skills in the experimental group had increased compared to those in the control group although there were no differences in writing scores between groups. The students' IL skills were graded by the rubric created by the librarian at that time. The authors also realized that a valid, reliable, and evidence-based rubric would be needed to measure student work. Therefore it was decided to use the Association of American Colleges \& Universities (AAC\&U) IL VALUE Rubric for grading the papers to bolster validity of the assessment. Even though the IL VALUE Rubric was recommended to evaluate a collection of work rather than a single work, we found that the dimensions of the IL skills described in the rubric were well aligned with the information literacy outcomes of the writing assignments. We adapted the rubric and ended up utilizing 3 among 5 dimensions which were plausible for scoring students papers.

\section{Participants}

Recruiting faculty was one of the most challenging aspects of the entire process of the project. As a recruiting method, the librarian, who is one of the authors of this paper, sent an email to each chair of the STEM departments asking to relay the message to faculty who might be interested in the study. No responses were received. The librarian decided to try a personal approach, making contact with faculty face to face or through emails. Only three faculty members volunteered to participate in the study: one faculty member from Biology (BI-356: Principles of Genetics), one from Engineering Technology (ET841: The Science of Energy and Power in the Modern World), and one from Mathematics (MA-336: Statistics). However, the MA-336 instructor was not scheduled to teach the same class in two consecutive semesters. This study was designed to compare two sections of the same class (experimental vs. control) taught by the same instructor. Therefore, MA-336 students were removed from the analysis. Included were the students who enrolled in a section of Biology (BI-356) and a section of Engineering Technology (ET-841) in the fall of 2017 and the spring of 2018.

BI-356 is designated as a writing intensive (WI) course and students must take BI-201(General Biology) with a $\mathrm{C}$ or better grade as a pre-requisite. BI-356 is a required course for students who want to transfer to a four-year college with Biotechnology as their major. Students were assigned to write a 4-5 research paper with a minimum of 3 references using a CSE format. Students could select one of the two topics given from the instructor: one was related to DNA fingerprinting and the other was about genetic differences between individual humans and groups of humans.

Although ET-841 is not a WI course, the instructor assigned writing projects to students. ET 841 is an elective course and has no pre-requisites. Students working towards an A.A.S. degree in Computer 
Engineering Technology, A.A.S. degree in Telecommunications Technology, A. S. degree in Environmental Science, or A. A.S. Degree in Electronic Engineering Technology could take ET-841 as an elective course. Students were assigned to write a 3-4 page long research paper with a minimum of 3 references using MLA format. The broad topic with specific examples was given to students: innovative technology and sustainability. Students were allowed to use not only scholarly sources but also mixed sources such as magazines or newspapers as long as they are reliable. However, they were strongly encouraged to use scholarly sources during the library session.

Library instruction was scheduled to be about 2 or 3weeks before the writing assignment due date, which was toward the end of semester. During the 50 minute library instruction for both BI-356 and ET841, students were introduced to evaluating sources (web evaluation and scholarly vs non-scholarly), keyword searching in the library databases, choosing scholarly articles, concept of plagiarism, and a brief demonstration about citing sources. Since time was limited, search strategies using Boolean connectors and truncation were excluded and lessons for citing sources in a format lasted only about 5 minutes.

Most students enrolled in BI-356 or ET-841 were not the first year students according to the survey conducted at the beginning of the fall semester of 2017 and the spring of 2018 (65\% and 69\% respectively). Most students also indicated that they planned to transfer to a 4-year college or university.

A total of 81 students participated in this study: 40 students in the fall of 2017 semester and 41 students in the spring of 2018 semester. Students who participated in the study received gift cards funded by the PSC-CUNY grant.

\section{Research Questions}

There were two main research questions for this project. (1) Do students improve IL skills after a oneshot library instruction? If they do improve, which IL skills improve the most? If they don't, which IL skills need to be improved? (2) Is there a relationship between IL skills and writing?

\section{Research Design}

The study focused on students enrolled in ET-841 and BI-365. Those who enrolled in the fall of 2017 ( $n$ $=40$ ) were selected as the experimental group and those who enrolled in the spring of $2018(n=41)$ were assigned to be in the control group. Students in the experimental group attended the one-shot library instruction (about 50 minutes), while no library instruction was offered to students in the control group. Each course was taught by the same instructor.

Students' papers were graded based on the Information Literacy VALUE Rubric created by the Association of American Colleges \& Universities (AAC\&U). The rubric has 5 dimensions, each with four levels of performance (Capstone: 4, Milestones: 3 and 2, and Benchmark: 1) defined by the AAC\&U:

Dimension 1: Determine the extent of information needed

Dimension 2: Access the needed information

Dimension 3: Evaluate information and its sources critically

Dimension 4: Use information effectively to accomplish a specific purpose

Dimension 5: Access and use information ethically and legally 
The authors agreed that it might be hard to capture dimension 1 and 2 just by reviewing the papers, therefore papers were graded based on the AAC\&U IL VALUE Rubric using only dimensions 3, 4, and 5.

\section{Data Collection and Analysis}

Faculty members emailed the students' papers to the author/librarian after they posted the grades at the end of each semester. The author/librarian removed the students' names, coded the papers, and gave them to two librarians who volunteered to score the papers based on AAC\&U IL VALUE Rubric (dimension 3, 4, and 5). The instructors did not know the students' IL scores and the scoring librarians had no knowledge of the students' grades on the papers or which group they belonged to. Student confidentiality was maintained and only the author/librarian had access to both scores.

Research question 1: Do students improve IL skills after a one-shot library instruction? For research question 1, independent-samples t-tests were conducted to compare the mean scores of information literacy (IL) skills (dimension 3, 4, and 5) on the papers between the students in the experimental group and those in the control group to examine if there was a significant difference. A total of 81 students participated and included in the t-tests.

Research question 2: Is there a relationship between IL skills and writing performance? For research question 2, the Pearson correlation coefficient test was used for examining the relationship between IL skills and students' grades on writing. The author/librarian received 81 papers electronically and librarians/volunteers scored them, but the author/librarian was not able to secure writing grades of 2 students in the control group from the instructor. As a result, a total of 79 students were included in the Pearson correlation test.

SPSS version 24 was used for analyzing all of the data.

\section{Results}

\section{Total IL VALUE (combined scores from dimension 3, 4, and 5) between groups}

There was a significant difference when looking at the sum of the three mean scores of dimensions 3, 4, and 5 for the experimental group $(n=40, M=9.70, S D=1.29)$ as compared to the control group $(n=$ $41, \mathrm{M}=8.73, S D=1.99), t(68.68)=2.61, p=.011, d=.58$. Students in the experimental group received higher IL scores than the students in the control group.

\section{Dimension 3: Evaluate Information and its Sources Critically}

There was a significant difference in mean scores of dimension 3 between the experimental group $(n=$ $40, \mathrm{M}=3.75, S D=.49)$ and control group $(n=41, \mathrm{M}=3.20, S D=.68), t(73.08)=4.22, p<.001, d=$ .93. Students in the experimental group were better able to evaluate information and choose sources appropriate to the topic after the one-shot library instruction than those in the control group who were not given a library instruction in the course.

\section{Dimension 4: Use Information Effectively to Accomplish a Specific Purpose}

No significant difference was found in mean scores of dimension 4 between the experimental group ( $n=$ $40, \mathrm{M}=2.93, S D=.76)$ and the control group $(n=41, \mathrm{M}=3.05, S D=.81), t(79)=-.71, p=.48$. The value of dimension 4 was testing how well students synthesized and organized information from 
sources. This includes paraphrasing, appropriate in-text citations, and how well the sources related to the topic. It turned out that students could not develop those skills just from one-shot library instruction.

\section{Dimension 5: Access and Use Information Ethically and Legally}

There was a significant difference in mean scores of dimension 5 between the experimental group $(n=$ $40, \mathrm{M}=3.03, \mathrm{SD}=.70)$ and the control group $(n=41, \mathrm{M}=2.49, S D=1.1), t(69)=2.67, p=.009, d=$ .59. After the one-shot library session, students were able to increase knowledge about ethical and legal use of information and make citations properly on their papers as compared to those who did not receive library instruction.

\section{Correlation between IL VALUE Score and Grade on Students Papers}

The grades of the papers in the experimental group did not differ from the grades of the papers in the control group. However, there was a positive correlation between the total IL scores and grades on students' papers, $r=.35, n=79, p=.002$. Regardless of which group the students belonged to, those who possessed high IL skills received the better grades on their papers.

\section{Correlations between IL Skills and Grade on Students Papers}

Grades on the papers between groups did not differ, but IL skills were positively correlated with grades whichever group students belonged to. Therefore we determined it was appropriate to examine the relationship between IL skills - dimension 3, 4, \& 5 and between IL skills \& grade to see which IL skills were related to one another and which sets of skills were related to grades. The positively correlated sets of skills were found between D3 \& D4 ( $r=.50, n=81, p<.001)$ and D3 \& D5 ( $r=.23, n=81, p=$ .038). Students who were able to evaluate information and its sources critically (D3) organized sources well (D4) and cited properly in their papers (D5) and vice versa. However, no relationship was found between skills of organizing and synthesizing sources (D4) and skills of accessing and using information ethically (D5), $r=.20, n=81, p=.075$ (see Table 1 ).

Writing grades were associated with D4 $(r=.31, n=79, p=.006)$ and D5 ( $r=.25, n=79, p=.027)$. Students who possessed skills of synthesizing information and citing sources properly obtained better grades in writing while skills of evaluating information and its sources critically (D3) were not correlated to grade, $r=.20, n=79, p=.078$ (see Table 1 ).

Table 1. Correlations between IL Skills (D3, D4, \& D5) and Writing

\begin{tabular}{|c|l|l|l|c|}
\hline & Writing & D3 & D4 & D5 \\
\hline Writing & -- & & & \\
\hline D3 & $p=.078$ & -- & & \\
\hline D4 & $p=.006^{*}$ & $p=.000^{* *}$ & -- & \\
\hline D5 & $p=.027^{*}$ & $p=.038^{*}$ & $p=.075$ & -- \\
\hline
\end{tabular}




\section{Discussion}

Overall, students could benefit from a one-shot library session in terms of evaluating sources (dimension 3) and using information legally and ethically (dimension 5). However, students from the experimental group were no better than the control group at incorporating sources into their writing (dimension 4). Studies have shared similar findings that students' skills of choosing quality of sources have been improved after library instruction (Kromer 2015; Zhang et al. 2015; Rose-Wiles et al. 2017). At the same time, studies also indicated problems with students' ability to use proper citations even after library instruction (Kromer 2015; Zhang et al., 2015; Albro et al. 2018). That was not the case with this study. Our students might have struggled with citations, but students in the experimental group did in fact do better with a library session than non-library attendees did.

It can be challenging for students to synthesize information and apply it in writing (Cope \& Sanabria 2014). But, these skills turned out to be related to writing performance in this study, which parallels the findings of Flierl et al. (2018): students who obtained the high-order skills such as synthesizing and communicating information performed better in writing. Building such high-order IL skills would take time and effort. As the study by Klucevsek and Brungard (2016) demonstrated, students were able to develop high cognitive IL skills after IL instruction was fully incorporated into a writing course and the embedded librarian provided a semester-long assistance such as feedback, IL instruction, and online guides.

It seemed that if students acquired knowledge of using information ethically, i.e., citing sources in a format, they did well at writing. When the writing assignments were examined from both the BI-365 and ET-841 classes, instructors clearly specified the inclusion of citations in a format. Students in the experimental group who attended the library session could have taken advantage of the library instruction even if the demonstration of citation was very brief.

Considering most students enrolled in BI-356 or ET-841 were not first year students, some students in the control group might have already been well-equipped with writing skills, while other students in the experimental group might not have been prepared for college level writing. That may explain why there was no difference in writing grade between groups. Moreover, instructors' expectations of the writing could have been different (Head \& Eisenberg 2010) and information literacy skills were actually composed of a small portion (less than 20\%) of the grade. There are other components that contribute to development of writing skills besides IL. It could simply be students' habits of reading and writing. As Verkade and Lim (2016) suggested, writing depends on how students read science journal articles. In other words, if students approached deep reading, they produced deep writing. But in general, reading scholarly scientific journal articles and incorporating them into a research paper can be a daunting task for community college students. Furthermore, according to the survey, a majority of those who enrolled in Bi-456 or ET-841 planned to transfer to a 4-year college or university. This might mean most of them were goal-oriented students and determined to complete course work regardless.

\section{Limitation \& Further Studies}

This study is limited because of a small sample size and cannot be representative for the community college as a whole. It included only quantitative data. Qualitative data would have added value to this study. As most participants in this study were in the second year with different levels of IL skills, it would have been better to evaluate students IL skills in both groups before the semester started. 
Recommendations for further studies include focus on IL in community college STEM fields in line with course curricula within the institution's mission and identify IL learning outcomes that are suitable for the community college level. Assessing impact of IL on learning outcomes could be a valuable tool to promote librarians' role in the community college. The authors would also like to urge academic librarians in community colleges or 2-year institutions to share findings on IL in STEM disciplines in both the scholarly literature and professional communities.

\section{Conclusion}

The one key takeaway from this study would be the positive correlation between information literacy skills and grade in STEM writing. The higher IL skills students possessed, the better writing grade they received. Another takeaway would be that writing grades were positively related to the IL skills of synthesizing information and using it ethically.

It appeared that skills of evaluating and using information critically and ethically could be developed in a short period of time, but synthesizing and organizing information would not be achievable with just one-shot library instruction. IL skills related to high-order skills such as organizing and synthesizing information turned out to affect writing performance. As Flierl et al. (2018) recommended, the library instruction should be designed to facilitate students' motivation so that students would develop highorder IL skills. It might be feasible if IL is fully integrated into writing courses for a longer period of time with multiple library sessions (Klucevsek \& Brungard 2016). It is essential to this study that librarians and faculty collaborated to facilitate these high cognitive skills because librarians by themselves would not be able to fulfill this goal (Waters 2015; Wilkes et al. 2015). Given the importance of collaboration with faculty, librarians should actively reach out to them, and prove to them the impact of IL instruction on student learning. This could be particularly important in STEM fields, where faculty may be less aware of IL. As Saunders (2012) suggested, if faculty were aware of IL and its effectiveness, they would be more likely to incorporate IL instruction into their courses.

\section{Acknowledgments}

Support for this project was provided by a PSC-CUNY Award, jointly funded by The Professional Staff Congress and The City University of New York for the 2017-2018 academic year. The authors would like to acknowledge two librarians, Professor Sheila Beck and Professor Devin McKay for their assistance in scoring students' papers.

\section{References}

Albro, M.H., Sheffield, K.M., Grant, A. \& Redd, R. 2018. Information literacy and mathematics education students: A case study in library instruction. Journal of New Librarianship 3(1): 58-65. DOI: $\underline{10.21173 / \text { newlibs/4/12. }}$.

American Library Association. 2006. Information Literacy Standards for Science and Engineering/Technology. Available at http://www.ala.org/acrl/standards/infolitscitech.

Association of American Colleges and Universities (AAC\&U). 2013. Information literacy VALUE Rubric. Available at https://www.aacu.org/value/rubrics/inquiry-analysis. 
Balint, D.M. 2016. Supporting information literacy development of engineering students in researchbased composition courses. Paper presented at the 2016 IEEE Global Engineering Education Conference (EDUCON). DOI: 10.1109/EDUCON.2016.7474645.

Barsky, E., Read, K. \& Greenwood, A. 2011. Teaching matters: Increasing library visibility through integrated classroom instruction. Canadian Journal of Library and Information Practice and Research 6(1): 1-5. DOI: 10.21083/partnership.v6i1.1448.

Bussmann, J.D. \& Bond, J.D. 2015. Information literacy in Mathematics undergraduate education: Where does it stand today? Issues in Science and Technology Librarianship 81. DOI: 10.5062/F4WM1BD8.

Catalano, A. \& Phillips, S. 2016. Information literacy and retention: A case study of the value of the library. Evidence Based Library and Information Practice 11(4): 2-13. DOI: 10.18438/B82K7W.

Cope, J. \& Sanabria, J.E. 2014. Do we speak the same language? A study of faculty perceptions of information literacy. portal: Libraries and the Academy 14(4): 475-501. DOI: 10.1353/pla.2014.0032.

Crawford, G.A. 2015. The academic library and student retention and graduation: An exploratory study. portal: Libraries and the Academy 15(1): 41-57. DOI: 10.1353/pla.2015.0003.

Dubicki, E. 2013. Faculty perceptions of students' information literacy skills competencies. Journal of Information Literacy 7(2): 97-125. DOI: 10.11645/7.2.1852.

Ferrer-Vinent, I. J. 2016. Programmatic and scaffolded information literacy embedded in the science curriculum. Science and Technology Libraries 35(4): 295-303. DOI: 10.1080/0194262X.2016.1214096.

Flierl, M., Bonem, E., Maybee, C. \& Fundator, R. 2018. Information literacy supporting student motivation and performance: Course-level analyses. Library and Information Science Research 40(1): 30-37. DOI: 10.1016/j.lisr.2018.03.001.

George, S. \& Munshi, T. 2016. Making students eat their greens: Information skills for chemistry students. Issues in Science and Technology Librarianship 85. DOI: 10.5062/F4CF9N42.

Gross, L.K., Chang, S. \& Dinneen, M. 2016. Strengthening information literacy in a writingdesignated course in the mathematics major. College \& Undergraduate Libraries 23(1): 56-78. DOI: $\underline{10.1080 / 10691316.2014 .933689 .}$.

Gullikson, S. 2006. Faculty Perceptions of ACRL's Information Literacy Competency Standards for Higher Education. Journal of Academic Librarianship 32(6): 583-592. DOI:

10.1016/j.acalib.2006.06.001.

Haddow, G. 2013. Academic library use and student retention: A quantitative analysis. Library \& Information Science Research 35:127-136. DOI: 10.1016/j.lisr.2012.12.002.

Head, A. \& Eisenberg, M. 2010. Assigning inquiry: How handouts for research assignments guide today's college students. Project Information Literacy. Available at https://www.projectinfolit.org/uploads/2/7/5/4/27541717/pil_handout_study_finalvjuly_2010.pdf. 
Henderson, F., Nunez-Rodriguez, N. \& Casari, W. 2011. Enhancing research skills and information literacy in community college science students. American Biology Teacher 73(5): 270-275. DOI: 10.1525/abt.2011.73.5.5.

Jantti, M. \& Cox, B. 2013. Measuring the value of library resources and student academic performance through relational datasets. Evidence Based Library \& Information Practice 8(2): 163-171. DOI: 10.18438/B8Q89F.

Klucevsek, K.M. \& Brungard, A.B. 2016. Information literacy in science writing: How students find, identify, and use scientific literature. International Journal of Science Education 38(17): 2573-2595. DOI: $\underline{10.1080 / 09500693.2016 .1253120 .}$.

Kromer, J. 2015. Impact of a library instruction session on bibliographies of organic chemistry students. Issues in Science and Technology Librarianship 82. DOI: 10.5062/F4M32SS9.

Leckie, G. \& Fullerton, A. 1999. Information literacy in science and engineering undergraduate education: Faculty attitudes and pedagogical practices. College \& Research Libraries 60(1):9-29. DOI: $\underline{10.5860 / \mathrm{crl} .60 .1 .9}$.

Library Journal. 2017. First year experience survey: Information literacy in higher education. Available at https://s3.amazonaws.com/WebVault/research/LJ_FirstYearExperienceSurvey_Mar2017.pdf.

McGuinness, C. 2006. What faculty think-Exploring the barriers to information literacy development in undergraduate education. Journal of Academic Librarianship 32(6): 573-582. DOI:

10.1016/j.acalib.2006.06.002.

Oakleaf, M. 2010. Value of academic libraries: A comprehensive research review and report. Chicago, IL: American Library Association. Available at http://www.ala.org/acrl/sites/ala.org.acrl/files/content/issues/value/val_report.pdf.

Oakleaf, M., Whyte, A., Lynema, E. \& Brown, M. 2017. Academic libraries \& institutional learning analytics: One path to integration. Journal of Academic Librarianship 43(5): 454-461. DOI: 10.1016/j.acalib.2017.08.008.

Perry, H.B. 2017. Information literacy in the sciences: Faculty perception of undergraduate student skill. College \& Research Libraries 78(7): 984-977. DOI: 10.5860/crl.78.7.964.

Phillips, M. \& Zwicky, D. 2018. Information literacy in engineering technology education: A case study. Journal of Engineering Technology 35(2): 48-57. Available at https://docs.lib.purdue.edu/lib_fsdocs/210/.

Poe, M. \& Lewitt, S. 2006. The four myths of writing: Changing science and engineering students' preconceptions about writing. International Journal of Writing 12(8): 57-62. DOI: 10.18848/14479494/CGP/v12i08/48041.

Rose-Wiles, L., Glenn, M. \& Stiskal, D. 2017. Enhancing information literacy using Bernard Lonergan's Generalized Empirical Method: A three-year case study in a first year biology course. Journal of Academic Librarianship 43(6): 495-508. DOI: 10.1016/j.acalib.2017.08.012. 
Salisbury, L. \& Mattice, G. 2016. Early exposure to the scientific research process through collaboration with chemistry faculty and the science librarian. Science \& Technology Libraries 35(2): 119-35. DOI: 10.1080/0194262X.2016.1162118.

Sandercock, P. 2016. Instructor perceptions of student information literacy. Journal of Information Literacy 10(1): 3-29. DOI: 10.11645/10.1.2065.

Saunders, L. 2012. Faculty perspectives on information literacy as a student learning outcome. Journal of Academic Librarianship 38(4): 226-236. DOI: 10.1016/j.acalib.2012.06.001.

Scaramozzino, J.M. 2010. Integrating STEM information competencies into an undergraduate curriculum. Journal of Library Administration 50(4): 315-333. DOI: 10.1080/01930821003666981.

Scharf, D. 2014. Instruction and assessment of information literacy among STEM majors. Paper presented at the 2014 IEEE Integrated STEM Education Conference (ISEC). DOI: 10.1109/ISECon.2014.6891048.

Sloane, M.E., Quintel, D.F. \& Groves, C. 2018. Lesson plan pilot project for physical science. Issues in Science and Technology Librarianship 90. DOI: 10.5062/F4765CKD.

Stebbing, D., Shelley, J., Warnes, M. \& McMaster, C. 2019. What academics really think about information literacy. Journal of Information Literacy 13(1): 21-44. DOI: 10.11645/13.1.2338.

Verkade, H. \& Lim, S.H. 2016. Undergraduate science students' attitudes toward and approaches to scientific reading and writing. Journal of College Science Teaching 45(4): 83-89.

Ward, L. \& Kim, M. 2019. Faculty perception of information literacy at Queensborough Community College. Community and Junior College Libraries 23:13-27. DOI: 10.1080/02763915.2018.1558899.

Waters, N. 2015. A poster assignment connects information literacy and writing skills. Issues in Science and Technology Librarianship. 80 DOI: 10.5062/F4K935JV.

Wengler, S. 2017. IL Sessions: Fall 2017. Internal QCC library report: unpublished.

Wilkes, J., Godwin, J. \& Gurney, L.J. 2015. Developing information literacy and academic writing skills through the collaborative design of an assessment task for first year engineering students. Australian Academic \& Research Libraries 46(3): 164-175. DOI: 10.1080/00048623.2015.1062260.

Zhang, Q., Goodman, M. \& Xie, S. 2015. Integrating library instruction into the course management system for a first-year engineering class: An evidence-based study measuring the effectiveness of blended learning on students' information literacy levels. College \& Research Libraries 76(7): 934-958. DOI: $10.5860 / \mathrm{crl}$.76.7.934.18. 